\title{
Exploring CRM effectiveness: an institutional theory perspective
}

\author{
Bas Hillebrand • Jurriaan J. Nijholt • Edwin J. Nijssen
}

Received: 25 June 2010 / Accepted: 28 January 2011 /Published online: 1 March 2011

(C) The Author(s) 2011. This article is published with open access at Springerlink.com

\begin{abstract}
This study identifies the potential contribution that institutional theory can make to understanding the success of marketing practices. Based on institutional theory, we argue that the effectiveness of marketing practices decreases when firms are motivated to adopt such practices under the influence of institutional pressures originating in firms' environments. However, alignment between a practice and a firm's marketing strategy may buffer against these negative effects. We apply these insights to the case of customer relationship management (CRM). CRM is considered an important way to enhance customer loyalty and firm performance, but it has also been criticized for being expensive and for not living up to expectations. Empirical data from 107 organizations confirm that, in general, adopting CRM for mimetic motives is likely to result in fewer customer insights as a result of using this practice. Our study suggests that institutional theory has much to offer to the investigation of the effectiveness of marketing practices.
\end{abstract}

Keywords Customer relationship management . Institutional theory - Mimetic motives · Adoption .

Marketing practices

B. Hillebrand $(\bowtie)$

Institute for Management Research,

Radboud University Nijmegen,

Nijmegen, Netherlands

e-mail: b.hillebrand@fm.ru.nl

J. J. Nijholt

Rotterdam School of Management, Erasmus University,

Rotterdam, Netherlands

\section{E. J. Nijssen}

Industrial Engineering \& Innovation Sciences,

Eindhoven University of Technology,

Eindhoven, Netherlands

\section{Introduction}

Institutional theory posits that the social context in which firms operate influences the behavior in and of organizations (Meyer and Rowan 1977), leading firms in an industry to adopt similar structures and practices. As opposed to theoretical accounts that take a strictly rational perspective on decision-making concerning practice adoption (Rogers 1995; Terlaak and Gong 2008), institutional theorists stress the role of social processes, norms and expectations in explaining firm behavior (Meyer and Rowan 1977). Varying actors in firms' environments exert pressures toward social conformity, leading firms to display similarities in the practices employed (DiMaggio and Powell 1983). Much of the research building on institutional theory therefore aims to explain homogeneity between organizations and sees diffusion speed and adoption decisions as important dependent variables (Burns and Wholey 1993; Tolbert and Zucker 1996).

Recently, institutional theorists have paid increasing attention to what happens after initial adoption of management practices, as they are implemented and acted upon in organizations (Ansari et al. 2010; Westphal et al. 1997). These researchers suggest that adoption under social pressure results in less attention for the technical efficiency of the management practice, which may influence its effectiveness. These ideas have not, however, been extended to marketing practices. Yet, against the backdrop of the trend toward more accountable marketing and in order to address the call to improve our understanding of the effectiveness and actual contribution of core marketing practices (Verhoef and Leeflang 2009), embracing institutional theory may be useful.

In line with these efforts, this study suggests that using institutional theory can make a contribution to understand- 
ing variation in effectiveness of marketing practices in firms. While institutional theory is rarely used in the field of marketing (Grewal and Dharwadkar 2002; Homburg et al. 1999; Iyer 1997; Rao et al. 2008), with the exception of studies focusing on explaining adoption of marketing practices (e.g., Wu et al. 2003), our paper will apply it to the case of a marketing practice that has recently been popular: customer relationship management (CRM).

The literature and popular press have reported significant variability in positive outcomes for firms using CRM. Empirical evidence suggests that, on average, CRM efforts contribute positively to firm performance (Krasnikov et al. 2009), but some studies have also found negative or insignificant results (Hendricks et al. 2006; Voss and Voss 2008; Yim et al. 2004). Furthermore, in the business press, examples of highly publicized CRM failures are rife. Dickie (2004) reports that only $25 \%$ of the firms that implemented CRM significantly improved their performance, while others suggest $60 \%$ of CRM projects end in failure (Payne 2006).

These contradicting empirical results raise the question of under what circumstances CRM stands a better chance of succeeding. In order to address this central research question we use insights from institutional theory and focus on how the motivations for adopting CRM influence CRM effectiveness, in terms of actually performing CRM activities as well as generating customer insights. Our focus on institutional theory is based on the observation that CRM has received a considerable amount of attention from consulting firms, the business press and the academic press (Krasnikov et al. 2009), leading some practitioners to posit that CRM has been "over-hyped" and "over-sold" (Whitmore and Copulsky 2003). We posit that these phenomena amount to institutional pressures on firms to adopt CRM, which lead to variation in the extent to which firms have mimetic motives for CRM adoption. In subsequent sections we propose and empirically test the consequences of these motives for CRM effectiveness. More specifically, the objective of this study is to empirically test a negative moderating influence of mimetic motives on a model specifying causal relationships between the degree to which firms have CRM systems in place, the degree to which they perform relational information processes, and the subsequent generation of customer insights. We thereby show that the sometimes disappointing results obtained by CRM are partly due to its very popularity.

The study contributes to the literature in two ways. First, successful application of insights derived from institutional theory to the case of CRM opens up new avenues for research in the marketing field; it may be used to better understand the effectiveness of other marketing practices. Second, our interest in the motives for adopting CRM dovetails with recent interest in the role of firm-related factors in explaining CRM performance (Krasnikov et al. 2009). However, our attempt to show the influence of institutional context is conceptually distinct from and complementary to previously established firm-related factors moderating or impacting CRM performance, such as customer relationship orientation (Jayachandran et al. 2005) and top management support (Campbell 2003).

The remainder of this paper is structured as follows. First, we briefly review institutional theory and mimetic motives, our baseline CRM model, and develop hypotheses regarding our conceptual extensions. Next, we explain our methodology and present the results. We close with a discussion of our findings and outline implications for future research.

\section{Mimetic motives}

In the organization literature there are two distinct perspectives on imitative behavior regarding the adoption of organizational structures and practices (Ansari et al. 2010; Haunschild and Miner 1997). First, the rational perspective predicts rational decision makers are able to weigh costs and benefits of available alternative practices and structures, and select accordingly. Imitative behavior is then a result of observing the performance or outcomes of other adopting firms and judging the appropriateness of the practice for the focal firm. As such, the rational perspective explains imitation through inferential learning and information cascades (Rao et al. 2008; Terlaak and Gong 2008).

In contrast, the institutional perspective, conceptualizing firms as operating in a social context, sees social pressures in the environment of firms as strong predictors for adoption and isomorphism across firms. Of a variety of institutional processes causing homogeneity, mimetic isomorphism has attracted the most academic attention (Mizruchi and Fein 1999), and a recent meta-analysis has found it to be the most important cause for isomorphism (Heugens and Lander 2009). Mimetic isomorphism occurs when organizations model themselves after the structures and practices of other organizations when they perceive the forms and practices of these others as appropriate or normatively sanctioned (Mizruchi and Fein 1999). As such, mimicry can occur regardless of considerations of specific technical or economic benefits for the adopting firm (Meyer and Rowan 1977).

The literature on institutional theory and management practices has paid considerable attention to explaining the occurrence of mimetic isomorphism. In the context of popular management practices, such as CRM, seeing that important competitors are adopting it, combined with a 
perception of it as "best practice," may cause powerful bandwagon effects that pressure other firms to adopt as well (Abrahamson 1991, 1996). Accompanied by intensive reporting by the business media as well as dissemination efforts by "management fashion setters" such as consulting firms and management gurus (Abrahamson 1996), popular practices become "normatively sanctioned" (DiMaggio and Powell 1983 , p. 153). This may motivate organizations to mimic the examples set forward by these fashion setters. In this process of social pressure, the question of whether practices are potentially beneficial for adopters becomes less susceptible to explicit and thorough evaluation (Oliver 1991; Tolbert and Zucker 1996), and the efficacy of the practice is "taken for granted" (Meyer and Rowan 1977, p. 344). Furthermore, displaying isomorphism with other firms in the field allows a firm to generate positive social evaluations (Abrahamson 1991) which, in turn, entail legitimacy benefits and lower the costs of acquiring vital resources.

This does not imply that all firms are equally influenced by such social pressures; firms are not deterministically governed by their social environment. In other words, managerial agency remains (Heugens and Lander 2009). Different decision makers and different decision-making processes are therefore heterogeneously influenced by institutional pressures, even if the latter are relatively uniform within and across industries (Kennedy and Fiss 2009; Oliver 1991). Consistent with this we suggest that firms vary in the extent to which their adoption decisions concerning CRM have been motivated by institutional pressures to mimic successful peers and powerful others. In this paper, we refer to this idea by introducing the concept of mimetic motives, defined as the extent to which a firm was motivated to adopt a practice (in this case CRM) by the mimetic pressures exerted on it by other adopters in the field, the popular business press, and management consulting firms.

Institutional theorists have suggested that social pressures are likely to have negative performance consequences for the use of a practice (Ansari et al. 2010; Westphal et al. 1997). Managers adopting a practice free from mimetic pressures are more likely to understand how the goals and mechanisms of the practice specifically fit within the context of their firm and be able to maximize the potential benefits (Ansari et al. 2010). Those adopters that respond to mimetic pressures, instead, are more concerned with appearing legitimate at the expense of a concern for, and understanding of, the technical value that a practice may have for the firm (Boiral 2007; Staw and Epstein 2000). Consequently, mimetic pressure may result in ceremonial adoption (Kostova and Roth 2002). Ceremonial adoption involves gaining legitimacy benefits of being an ostensible adopter of a new and innovative practice, while performing little or none of the activities typically associated with that practice (Lounsbury 2001; Westphal and Zajac 2001). Ceremonial adopters lack "internalization" of the practice because they are not convinced of its value or because they fail to understand the demands and requirements of the practice. As a result they may gravitate toward standard solutions that are less likely to be customized and fit their specific business context, thus compromising the economic effectiveness of the practice. For instance, Westphal et al. (1997) found that hospitals driven by mimetic motives implemented total quality management (TQM) without careful adaptation and as a result were less likely to realize the technical and economic benefits of TQM. In contrast, hospitals that adopted free from mimetic pressures were more likely to customize TQM and did experience important efficiency gains.

Independent of the extent to which mimetic motives are key drivers of adoption decisions, some organizations may display a better fit with particular practices than others (Guillén 1994; Kostova and Roth 2002). Particularly in the case of strategic fit, the philosophy and technology supporting a practice will be more easily aligned with existing configurations of resources, practices, and even knowledge, values and norms. When such alignment is present, practice implementation is labeled as being higher "fidelity" (Ansari et al. 2010) given a practice's set of intended goals. Under these conditions firms are more likely to experiment with the practice and customize it to their context and needs, increasing its final effectiveness (Wouters and Wilderom 2008). Moreover, a firm with a high fit between its strategy and the practice is likely to implement the practice more thoroughly even when institutional pressures played a large role in the adoption decision. Consequently, it is not just mimetic motives that influence CRM effectiveness. Rather it is the combination of mimetic motives and a firm's strategy that should be taken into account.

We will now develop a conceptual model to explain in more detail how mimetic motives may impact CRM effectiveness.

\section{Conceptual model}

For our study of the effects of mimetic motives on CRM effectiveness we use a model based on the extant CRM literature (see Fig. 1). It consists of (1) a CRM model, indicating how the availability of a more elaborate and automated CRM system leads to increased customer relational information processing and better customer insights, and subsequently increased customer relationship performance or loyalty, and (2) the moderating impact of mimetic motives on this CRM model, including the impact of its joint effect with a firm's strategic orientation toward customers. 
Fig. 1 Conceptual model of the moderating influence of mimetic motives of CRM adoption on CRM effectiveness

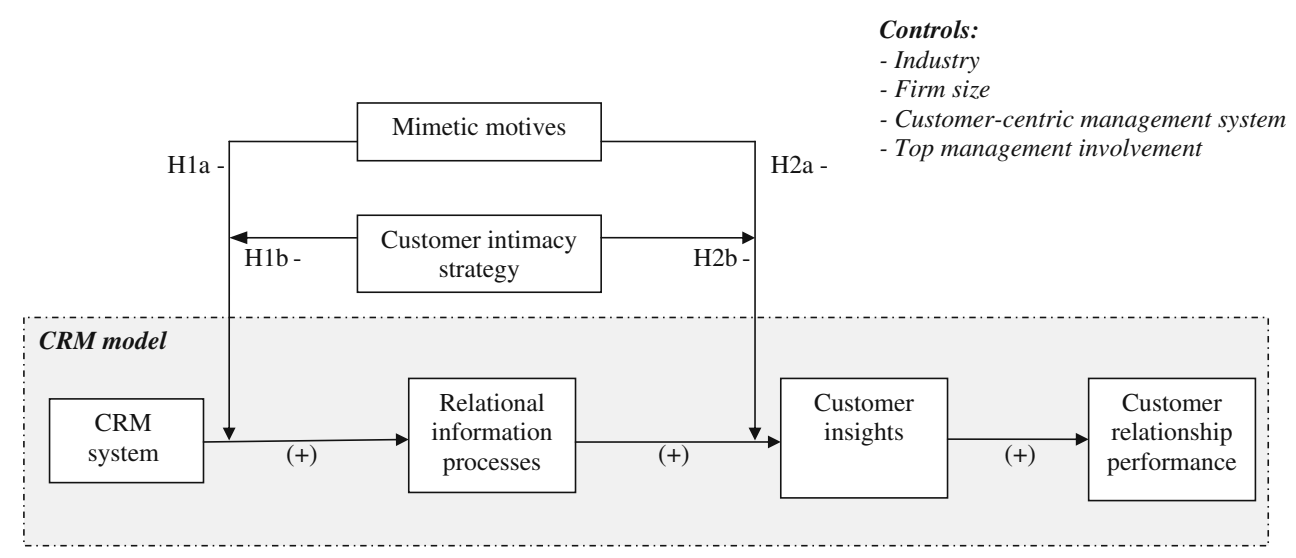

As the relationships of the CRM model are wellresearched and do not represent the main contribution of our study, we only retest these relationships and do not formulate formal hypotheses for them. After a brief discussion of the CRM model, we focus on the relationships that represent the effects of mimetic motives. Since we are especially interested in the various interaction effects of our main variables on the left-hand and right-hand sides of the model, respectively, we have chosen to discuss our hypotheses in that order as well.

\section{CRM model}

The logic of CRM encourages firms to move away from a product-focused toward a more customer-focused approach of doing business (Reinartz et al. 2004). Managing customer relationships for value is considered to reflect the essence of the marketing concept and the market orientation literature (Kohli and Jaworski 1990; Morgan and Hunt 1994; Narver and Slater 1990). It is seen as one of the core business processes as well as a strategic imperative (Bohling et al. 2006; Srivastava et al. 1999).

In line with previous studies (e.g., Jayachandran et al. 2005; Reinartz et al. 2004) we distinguish between CRM systems and relational information processes. CRM systems are the degree to which a firm has hardware and software in place intended for the input and storage of customer data, integration across organizational functions, as well as customer data analysis. Relational information processing refers to the degree to which a firm is actually engaged in the systematic registration, integration and analysis of this customer information (Jayachandran et al. 2005).

Research in the field of information systems shows that information technology may enhance the flow of information within an organization, making it easier to store customer data and increasing information accessibility (Alavi and Leidner 2001; Robey et al. 2000). It allows for the storage, retrieval, dissemination, and use of customer information for decisions regarding the initiation, building and termination of customer relationships. As CRM systems make it easier to process and access customer information, managers and frontline employees are expected to actually use it. In line with most CRM literature (e.g., Jayachandran et al. 2005; Reinartz et al. 2004) we thus suggest that having CRM systems in place results in more relational information processes.

The well-established positive relationship of relational information processes on customer relationship performance or firm performance (Jayachandran et al. 2005; Reinartz et al. 2004; Srinivasan and Moorman 2005) is mediated by the customer insights generated by the information processing activities (Mithas et al. 2005). Customer insights are defined as the degree to which a firm has an understanding of current customer needs, the reasons behind these needs, and how these change over time. Giving such a central place to customer knowledge fits well with the extant literature on market orientation and organizational learning (Sinkula 1994; Slater and Narver 1995), which has indicated that firms learn about their customers by registering, integrating, and analyzing customer information. So, the extent to which firms process relational information affects the amount of customer insights they acquire (Boulding et al. 2005; Mithas et al. 2005). These insights, in turn, should lead to enhanced customer relationship performance, i.e., customer retention. Having customer insights helps firms to tailor offerings to customer requirements and establish enduring customer relationships by creating and delivering additional customer value (Homburg et al. 2008; Mithas et al. 2005) and thus increases a firm's customer relationship performance.

Mimetic motives, customer intimacy strategy and relational information processes

With reference to Fig. 1, this section discusses the hypotheses we formulate for the left-hand side of the model. While mimetic adopters may hope to achieve performance benefits with the application of CRM, the potential focus 
on simply appearing legitimate (Boiral 2007; Kostova and Roth 2002 Staw and Epstein 2000) is likely to reduce CRM effectiveness in terms of relational information processes.

Mimetic motives will especially be relevant in situations where "organizational technologies are poorly understood [or] when goals are ambiguous" (DiMaggio and Powell 1983, p. 151). Against this background, it is salient to note that CRM is a practice with a large technological component, and that many commentators have criticized adopters for overemphasizing technology at the expense of the true goal of CRM (Reinartz et al. 2004). As a result, such firms tend to lack a deep understanding of the meaning and working of CRM, which in turn is likely to reduce the effectiveness of the technology and practice. It may lead to more superficial use and reduced efforts to improve the functioning of the CRM system (cf. Kostova and Roth 2002; Lounsbury 2001). Whereas many authors refer to a need to adjust organizational processes and customize CRM systems (Bohling et al. 2006; Campbell 2003; Homburg et al. 2008), such efforts may be underestimated or even overlooked when mimetic motives dominate. So, although having a CRM system in place is likely to lead to at least some increase in the registration, integration and analysis of customer information under all circumstances, in situations of high mimetic motives a firm will experience a positive but less strong benefit from having a CRM system in place than when such mimetic motives are absent; high mimetic motives will result in less effective system use and thus more limited increase in relational information processing. Thus, we hypothesize:

H1a: Mimetic motives have a negative moderating influence on the relationship between CRM system and relational information processes.

As argued above, the effects of mimetic motives for CRM adoption may be contingent on the degree to which firms follow a strategy that is aimed at putting the customer first (e.g., Bohling et al. 2006). Studies on management practices (such as ERP and e-commerce) have frequently taken a contingency approach and shown that the adoption and effectiveness of these management practices depend on firm strategy (e.g., Huang et al. 2010; Stratman 2007). In the case of CRM, especially the firm's focus on the customer seems a relevant strategic dimension (Krasnikov et al. 2009). Therefore, we introduce the concept of customer intimacy strategy (Treacy and Wiersema 1993), defined as the degree to which the firm's strategy is aimed at building strong customer relationships to be better able to exactly deliver offerings that customers need. Even if institutional pressures play a large role in the adoption decision, the extent to which a firm's strategy fits with the practice allows them to understand, internalize and customize the mechanisms of the practice easier than adopters for which such strategic fit is absent. Specifically, we posit that firms with a stronger customer intimacy strategy have a better fit with CRM. Firms that pursue such a strategy consider building long lasting customer relationships as part of creating customer value paramount (Treacy and Wiersema 1993) which fits the ideas behind the CRM practice (Srivastava et al. 1999).

When customer intimacy strategy is high, a firm is likely to be in a position to more easily grasp the technical possibilities of CRM systems and understand how a proper use of them may benefit the firm once the adoption decision has been made (cf. Wouters and Wilderom 2008). In other words, a firm's orientation on and involvement with developing and maintaining customer relationships helps the firm to understand and implement the CRM system in a correct way. This ability may buffer firms from the negative consequences of mimetic motives for the positive relationship between CRM system and relational information processes. In short, when customer intimacy strategy is high (low) the negative moderating effect of mimetic motives will be less (more) strong. This leads us to hypothesize the following negative three-way interaction:

H1b: Customer intimacy strategy has a negative moderating influence on the mimetic motives $\mathrm{x}$ CRM system interaction affecting relational information processes.

Mimetic motives, customer intimacy strategy and customer insights

With reference to Fig. 1, here we discuss the hypothesized interactions on the right-hand side of the model. While the systematic registration, integration and analysis of customer information should yield at least some increase in customer insights, such knowledge gains are likely to be lower when firms have initiated and implemented CRM for mimetic motives. This is because firms responding to institutional pressures will tend to a perfunctory and "mechanical" performance (Kostova and Roth 2002) of the associated relational information processes. These firms lack the full understanding of the goals and principles behind these information processes, since they are more likely to regard it as a set of standard procedures rather than a practice that requires careful adaptation and customization to a firm's context (Payne and Frow 2005). This reduces the effectiveness of relational information processes. Therefore, we propose a negative moderating impact of mimetic motives on the (positive) relationship between relational information processes and customer insights. More formally:

H2a: Mimetic motives have a negative moderating influence on the relationship between relational information processes and customer insights. 
As with the left-hand side of the model, we take a contingency approach here and suggest that the effects of mimetic motives are themselves moderated by the extent to which firms follow a customer intimacy strategy. Specifically, we expect that a customer intimacy strategy can buffer against the expected negative moderation of mimetic motives on the relationship between relational information processes and customer insight. Firms that are more focused on, and intimate with, their customers are in a better position to learn from their information processes. When customer intimacy strategy is high, firms can easily grasp the philosophy of customer relationship management and understand how customer information processes can contribute to the generation of customer insights. As a result, they will be able to extract more, and more valuable, customer insights from their information processes, even when they adopted CRM for mimetic reasons. In other words, the negative effects of mimetic motives brought about by a lack of internalization of CRM's philosophy and goals, are mitigated by a firm's customer-focused strategy. Hence,

$\mathrm{H} 2 \mathrm{~b}$ : Customer intimacy strategy has a negative moderating influence on the mimetic motives $x$ relational information processes interaction affecting customer insights.

\section{Covariates}

We add four covariates to ensure correct estimation of the model. First, the extant CRM literature suggests that the degree to which firms have tailored business processes toward serving customers may be important in explaining CRM adoption and success (Jayachandran et al. 2005; Raman et al. 2006; Reinartz et al. 2004). We refer to this here as customer-centric management systems (Jayachandran et al. 2005). Including this covariate ensures that the effects of mimetic motives are not confounded with the effects from a lack of general customer orientation in the design of business processes. Second, CRM literature also suggests that top management may be an important driver behind the adoption and success of CRM (Bohling et al. 2006; Homburg et al. 2008). To control for this we include top management involvement, which we define as the degree to which top management was actively participating in the decision making regarding the adoption and implementation of CRM. Third, we control for firm size because large firms are more likely to have internal expertise to more carefully evaluate new marketing/sales practices and related technology. Large firms may also have less resource constraints in general. Fourth, with relationships generally believed to be more important in service contexts (Palmatier et al. 2006), CRM may be more important for service firms compared to their manufacturing counter- parts. We therefore also control for the physical products/ services sector distinction, from now on referred to as industry.

\section{Method}

Sample and data collection

We test our framework using a sample of Dutch marketing and account managers of business-to-business firms. Key informants were randomly selected from membership lists of the Dutch Society of Sales and Account Managers. Members of this society are senior marketing and sales managers, which represent an appropriate target audience for our study considering the focus on motivations for CRM adoption and required reporting on context of use of CRM (see, e.g., Reinartz et al. (2004) for a similar approach). In 2006, 459 senior managers were approached using a personalized e-mail message to ask for their cooperation. The e-mail included a password and web-link to an electronic questionnaire. A small financial incentive ( 5 vouchers of $€ 40$ ) and a summary of the results were used to increase response rate. Several reminders were sent and people who had started filling in the questionnaire but did not finish it after 3 weeks were called. This resulted in a usable response of 117 managers and a response rate of $25.5 \%{ }^{1}$ Next, we checked for nonresponse bias by comparing early (first 3 weeks) with late respondents (Armstrong and Overton 1977). No difference in the main study variables between early and late respondents was detected. Finally, in the analysis stage seven cases were lost due to missing values in the control variables, while three outliers were also removed, leaving us with a net sample of 107 cases.

Respondents are mainly men (91\%) and between 30 and 40 years old (50\%). All managers confirmed working at the corporate or SBU levels. A majority of the respondents (77\%) work at small- or medium-sized firms, i.e., firms with less than 250 employees. Manufacturing firms were somewhat over-represented in the sample compared to service firms (53\% and $47 \%$ respectively). Dominant product-based sectors included electrical products (14.5\%) and construction and interior products (6.9\%). Dominant service sectors included HRM-training services (13.7\%) and management consulting (12.8\%).

\section{Measures}

We provide an overview of the measures for all study constructs used in Appendix A. All constructs were

\footnotetext{
${ }^{1}$ This excludes 24 respondents who indicated to have no or minimal CRM-like systems, which represents $5.2 \%$ of the people approached.
} 
measured using seven-point scales using "strongly disagree" and "strongly agree" as the anchors.

CRM system was measured using a scale specifically developed for this study but was inspired by the work of especially Reinartz et al. (2004) and Jayachandran et al. (2005) on CRM technology. Our five items capture whether the organization has such technology embedded within other technical and communication systems within the organization.

In line with its definition relational information processes is modeled as a second order reflective construct with three dimensions. The items for these three dimensions were adopted from Jayachandran et al. (2005). To emphasize the systematic nature of integration and data analyses we slightly modified some items and deleted two items (referring to 'selecting the best customer' and assessing lifetime value) that were felt to be a bit difficult to answer for most managers. This resulted in a 14-item scale.

Customer insights was measured by eight items, developed especially for this study and based on Woodruff's (1997) discussion of the customer value determination process. Woodruff (1997) argues that learning about customer value requires firms to answer critical questions about their customers, including questions about what it is in a product that customers value, what underlies these customer values, how they change, and how customers feel about their relationship and communication with the supplier. Our items reflect these critical questions.

Customer relationship performance was operationalized by three items capturing the degree to which a firm manages to create customer retention as perceived by the respondent in terms of positive word of mouth, repeat purchases and being loyal to the firm. As a performance indicator, it is particularly meaningful to ask respondents to assess it relative to performance by competitors (Conant et al. 1990).

Mimetic motives is a measure of the extent to which a firm was motivated to adopt CRM by the mimetic pressures exerted by other adopters in the field, the popular business press, and management consulting firms. Our three items capture the extent to which respondents believed these sources of mimetic pressure to be influential in their firm's decision making regarding CRM adoption and were inspired by the work of Abrahamson (1996) and Westphal et al. (1997). Note that the items are formulated in a passive way ("in response to," "influenced by") so that respondents were asked to acknowledge social influences on adoption.

Customer intimacy strategy was also developed for this research and was inspired by Treacy and Wiersema's (1993) seminal text introducing this concept. The three items used address the level of relational focus in the customer relationship, customizing products and the best products for the customer's needs.
Customer-centric management system, our first covariate, was measured by three items adopted from the scale by Jayachandran et al. (2005). Top management involvement was measured by three items based on Campbell (2003) and Bohling et al. (2006). Firm size was measured by the number of fulltime equivalent employees. For industry (i.e., physical products versus services sector) we used a dummy variable.

\section{Analyses}

We used SPSS 15 and Smart PLS 2.0 to analyze the data in two principal stages. First, we examined the descriptive statistics, used exploratory factor analyses and computed internal consistencies according to their composite reliability (Fornell and Larcker 1981). All reliabilities exceed Nunnally's (1978) guideline of greater than .70 (see Table 1), with the lowest score being .74. Convergent validity is satisfactory as the average variance extracted is higher than .5 for all study constructs (Fornell and Larcker 1981). To explore the external validity of our main construct, mimetic motives, we refer to the correlation matrix (see Table 1). Note that it has a significant positive correlation with top management involvement, no correlation with customer insights, and a significant negative correlation with customer intimacy strategy. This provides some evidence for the external validity of our measure as one would anticipate positive relations with management's decision making and negative or no relationships with customer intimacy strategy and insights. To research the discriminant validity of the study constructs, we use Fornell and Larcker's (1981) test, which requires that a construct shares more variance with its measures than it shares with other constructs in a given model. As we show in Table 1, for all constructs the average variance extracted is higher than the squared correlations between the construct and all other study constructs. ${ }^{2}$ Together, these results suggest that the measures are acceptable and meet the criteria of convergent and discriminant validity.

Second, we used SmartPLS (2.0) to obtain partial least squares (PLS) estimates for both the structural and measurement parameters in our structural equation model (Chin 1998; Ringle et al. 2005). The use of PLS analysis is appropriate here since our sample size is relatively small (Barclay et al. 1995; Reinartz et al. 2009). To test the effects and statistical significance of the hypothesized pathways in the structural model, we use Smart PLS's bootstrapping option with 500 samples, as recommended to obtain stable results (Chin 1998). For estimating the second order constructs, we averaged the items of the first order

\footnotetext{
${ }^{2}$ The correlations and means were calculated based on the latent variable scores from PLS using SPSS software.
} 
Table 1 Means, standard deviations, scale reliabilities, $\mathrm{AVE}^{\mathrm{a}}$ and correlations

\begin{tabular}{|c|c|c|c|c|c|c|c|c|c|c|c|}
\hline & Mean & S.D. & Composite Reliability ${ }^{\mathrm{b}}$ & 1 & 2 & 3 & 4 & 5 & 6 & 7 & 8 \\
\hline 1. CRM system & 3.91 & 1.22 & .83 & $.53^{\mathrm{a}}$ & $.01^{\mathrm{c}}$ & .44 & .01 & .02 & .04 & .15 & .23 \\
\hline 2. Mimetic motives & 1.91 & 1.09 & .84 & $.12^{\mathrm{d}}$ & .75 & .04 & .00 & .05 & .00 & .01 & .04 \\
\hline 3. Relational information processes & 3.62 & 1.18 & .86 & .66 & .21 & .79 & .23 & .05 & .04 & .32 & .17 \\
\hline 4. Customer insights & 4.15 & 0.95 & .90 & .12 & -.01 & .48 & .83 & .24 & .09 & .10 & .00 \\
\hline 5. Customer intimacy strategy & 4.80 & 0.90 & .74 & .13 & -.23 & .23 & .49 & .65 & .26 & .09 & .04 \\
\hline 6. Customer relationship performance & 4.83 & 0.84 & .79 & .20 & -.07 & .21 & .30 & .51 & .69 & .04 & .01 \\
\hline 7. Customer-centric management system & 4.14 & 1.13 & .75 & .39 & .12 & .57 & .31 & .30 & .19 & .66 & .12 \\
\hline 8. Top management involvement & 3.72 & 1.52 & .82 & .48 & .20 & .41 & .05 & .20 & .12 & .35 & .84 \\
\hline
\end{tabular}

${ }^{\mathrm{a}} \mathrm{AVE}=$ average variance extracted (for each construct reported on the diagonal of the matrix)

${ }^{\mathrm{b}}$ Composite reliabilities are Cronbach's alpha scores

${ }^{\mathrm{c}}$ Shared variances are reported in the upper half of the matrix

${ }^{\mathrm{d}}$ Correlations are reported in the lower half of the matrix. Correlations of .20 and above are significant at the $95 \%$ level

dimensions and used these aggregate measures as indicators for the second order construct in the PLS estimation. Further, for a correct estimation of the hypothesized moderation effects we added the direct effects of our two moderators (mimetic motives and customer intimacy strategy) on relational information processes and customer insights as well as all two-way effects between the moderators and CRM system and relational information processes (Aiken and West 1991). To estimate the threeway effects we first estimated and saved the latent variable scores of the two-way effects, and then entered them as indicators of the associated two-way constructs in the model estimated using the PLS software. Simple slope analysis (Aiken and West 1991) was used to facilitate the interpretation of these moderation effects, specifically the three-way interactions. This analysis makes insightful how mimetic motives affect the proposed CRM model by showing how the moderated relationships behave under different scores of the moderator variable(s) (one standard deviation above or below the mean).

Because common method bias is a concern when utilizing a survey instrument to measure both independent and dependent variables, Harman's one factor test was used to assess this potential problem. If common method bias is present, conducting an unrotated factor analysis on a survey's items should result in one factor emerging that accounts for the majority of the variance in the items (Podsakoff and Organ 1986). An unrotated factor analysis including all of survey items results in eleven factors explaining $73.0 \%$ of variance, with the largest single factor accounting for only $28.4 \%$ of the variance. Furthermore, it has been suggested that the smallest observed correlation between variables included in the model may function as a proxy for common method bias (Lindell and Brandt 2000). Table 1 shows that the smallest correlation between our model variables is -.01 .
These results suggest that common method bias is not a problem.

Finally, the appropriateness of using a linear $\operatorname{model}^{3}$ was tested by comparing its explained variances with the explained variances of a model including non-linear relationships. These tests indicated that the inclusion of non-linear relationships did not significantly increase the adjusted $\mathrm{R}^{2}$ of any of the three dependent variables $(p>.10)$. As such we consider our decision to model linear relationships justified.

\section{Results}

Table 2 presents the results of the data analysis. The explained variance (adjusted $\mathrm{R}^{2}$ ) of the dependent variables in our model is .63 for relational information processes, .48 for customer insights, and .11 for customer relationship performance. ${ }^{4}$ Compared to other CRM studies (e.g., Jayachandran et al. 2005) these figures may be considered satisfactory, particularly as explaining variation in performance is not the main purpose of our study and customer relationship performance is added merely to demonstrate an overall positive effect of customer insights.

As Table 2 indicates, our results support the baseline CRM model. The degree to which firms have a CRM system in place positively influences the degree to which these firms engage in relational information processes $(b=.84, p<.01)$. Relational information processes, in turn,

\footnotetext{
${ }^{3}$ We thank an anonymous reviewer for suggesting this additional test. ${ }^{4}$ Considering adjusted $\mathrm{R}^{2}$ (instead of $\mathrm{R}^{2}$ ) is important in our case as we have a limited dataset and a relatively large set of indicators (p). PLS does not allow for a calculation of adjusted $\mathrm{R}^{2}$, but we computed it using the formula $1-\left(1-\mathrm{R}^{2}\right)^{*}(\mathrm{n}-1) /(\mathrm{n}-\mathrm{p}) /(\mathrm{n}-\mathrm{p}-1)$. We thank the reviewers for advice.
} 
Table 2 PLS results of estimated coefficients

Relational information Customer insights processes
Customer relationship performance

Path coeff (s.d.) T-value Path coeff (s.d.) T-value Path coeff (s.d.) T-value

\begin{tabular}{|c|c|c|c|c|c|c|}
\hline \multicolumn{7}{|l|}{ Direct Effects } \\
\hline CRM system & $0.84(.16)$ & $5.1 * * *$ & & & & \\
\hline Relational information processes & & & $0.61(.21)$ & $2.8 * * *$ & & \\
\hline Customer insights & & & & & $0.32(.10)$ & $3.2 * *$ \\
\hline Mimetic motives & $-0.09(.10)$ & 1.0 & $-0.09(.10)$ & 0.9 & & \\
\hline Customer intimacy strategy & $0.28(.10)$ & $2.7 * *$ & $0.27(.11)$ & $2.4 * *$ & & \\
\hline \multicolumn{7}{|l|}{ 2-way Interaction Effects } \\
\hline Mimetic motives $\mathrm{x}$ CRM system & $0.20(.12)$ & 1.6 & & & & \\
\hline Customer intimacy strategy x CRM system & $-0.28(.15)$ & $1.9^{*}$ & & & & \\
\hline Mimetic motives x Customer intimacy strategy & $0.21(.12)$ & $1.8^{*}$ & $0.21(.12)$ & $1.7^{*}$ & & \\
\hline Mimetic motives $\mathrm{x}$ Relational information processes & & & $-0.20(.12)$ & $1.7^{*}$ & & \\
\hline Customer intimacy strategy $\mathrm{x}$ Relational information processes & & & $-0.17(.14)$ & 1.2 & & \\
\hline \multicolumn{7}{|l|}{ 3-way Interaction Effects } \\
\hline Customer intimacy strategy $\mathrm{x}$ Mimetic motives x CRM system & $-0.40(.17)$ & $2.4 * *$ & & & & \\
\hline $\begin{array}{l}\text { Customer intimacy strategy x Mimetic motives x Relational } \\
\text { information processes }\end{array}$ & & & $0.13(.11)$ & 1.1 & & \\
\hline \multicolumn{7}{|l|}{ Control Variables } \\
\hline Industry (product vs. service) & $0.11(.06)$ & $1.8^{*}$ & $0.06(.06)$ & 1.1 & $-0.17(.09)$ & $1.9^{*}$ \\
\hline Firm size & $-0.10(.05)$ & $1.9^{*}$ & $-0.01(.06)$ & 0.2 & $0.05(.06)$ & 0.7 \\
\hline Customer-centric management system & $0.24(.07)$ & 1.2 & $-0.04(.08)$ & 0.5 & $0.08(.07)$ & 1.1 \\
\hline Top management involvement & $-0.09(.05)$ & 1.6 & $-0.24(.09)$ & $2.5^{* *}$ & $0.14(.09)$ & $1.7^{*}$ \\
\hline Adjusted $\mathrm{R}^{2}$ & 0.63 & & 0.48 & & 0.11 & \\
\hline
\end{tabular}

$* * * p<.01 ; * * p<.05 ; * p<.1$ (2-tailed)

show a significant positive path to customer insights $(b=.61$, $p<.01)$. Furthermore, customer insights positively affect customer relationship performance $(b=.32, p<.01)$. Together, these results are consistent with previous findings in the CRM literature.

In order to give some additional support for the usefulness of our focus on the moderating effects of mimetic motives in explaining CRM effectiveness, ${ }^{5}$ we analyzed the model as described above without the interaction effects of mimetic motives to observe differences in adjusted $\mathrm{R}^{2}$. Adding the interaction effects of mimetic motives results in a significant increase in adjusted $\mathrm{R}^{2}$ for relational information processes and customer insights of $\Delta .04$ and .07 (both $p<.05$ ), respectively. Thus, in support of the institutional approach, the addition of the moderations of mimetic motives enhances the level of variance in CRM effectiveness explained by the model. We now turn to a discussion of the interaction effects on the left and right-hand sides of the model.

\footnotetext{
$\overline{{ }^{5} \text { We thank an }}$ anonymous reviewer for suggesting this additional analysis.
}

Interaction effects on relational information processes

Turning to the hypotheses testing, we first focus on the moderation effects of mimetic motives and customer intimacy strategy concerning the relationship between CRM system and relational information processes, i.e., the left-hand side of the model.

Hypothesis 1a proposed a negative moderation effect from mimetic motives on the relationship between CRM system and relational information processes. As Table 2 shows this relationship is not significant $(b=.20, p>.10)$, and thus empirical findings fail to support Hypothesis 1a.

Hypothesis $1 \mathrm{~b}$ proposed a three-way interaction of CRM system, mimetic motives and customer intimacy strategy on relational information processes. The empirical data show that this three-way interaction is negative and significant $(b=-.40$, $p<.05$ ), thus supporting this hypothesis. Plotting the interactions (see Fig. 2) reveals that in situations of high customer intimacy strategy (i.e., one standard deviation above the mean), mimetic motives negatively affect the relationship between CRM system and relational information processes. However, when customer intimacy strategy is low (i.e., one standard deviation below the mean) the relationship between 
Fig. 2 Plots of 3-way effect mimic motives $X$ customer intimacy strategy on CRM system-relational information processes relationship

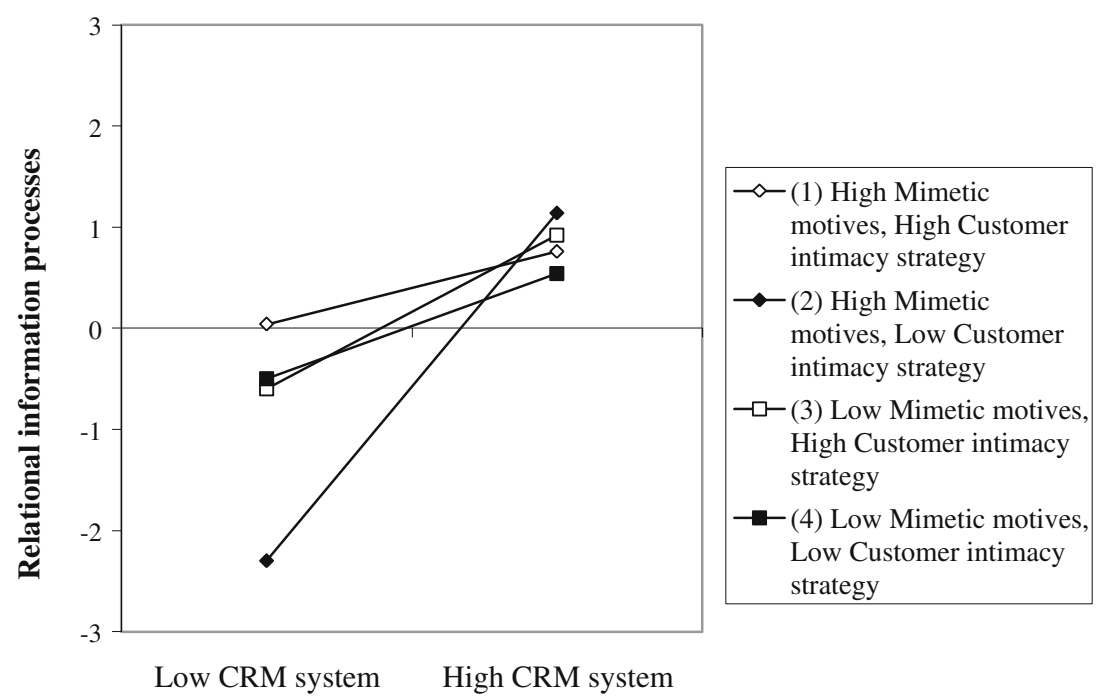

CRM system and relational information processes becomes stronger as judged by the increase in slope between "low" mimetic motives and "high" mimetic motives. It implies that firms which are (a) not pursuing a strategy of customer intimacy, but are (b) strongly influenced by mimetic pressures in their environment, end up processing more rather than less customer information when they increase their level of CRM systems.

Please note that Fig. 2 shows that only when firms score low on customer intimacy strategy and have invested limitedly in CRM (i.e., a low degree of CRM system), there is a notable difference in slope between a high and a low degree of mimetic motives. A combination of high mimetic motives, a low degree of customer intimacy strategy and limited investment in CRM system turns out to be detrimental in terms of processing customer information. This situation seems to represent cases of clear ceremonial adoption, with firms merely paying "lip service" to CRM. Under the condition of high customer intimacy strategy, the moderating effect of mimetic motives is, however, far less detrimental, which confirms that customer intimacy strategy has a buffering or compensating role.

Interaction effects on customer insights

The interaction effects of mimetic motives and customer intimacy strategy concerning the relationship between relational information processes and customer insights, i.e., the right-hand side of the model, paint a very different picture. Hypothesis 2a predicted a negative impact of mimetic motives on the relationship between relational information processes and customer insights. The PLS results in Table 2 confirm this negative, if marginally significant, moderating effect of mimetic motives $(b=-.20$, $p<.10$ ). Simple slope analysis (see Fig. 3) confirms that when mimetic motives are high, the impact of relational information processes on customer insights is weaker than when mimetic motives are low.

The hypothesized three-way interaction between mimetic motives, customer intimacy strategy and relational information processes on customer insights, i.e., Hypothesis 2b,
Fig. 3 Plots of 2-way effect mimic motives on relational information processescustomer insights relationship

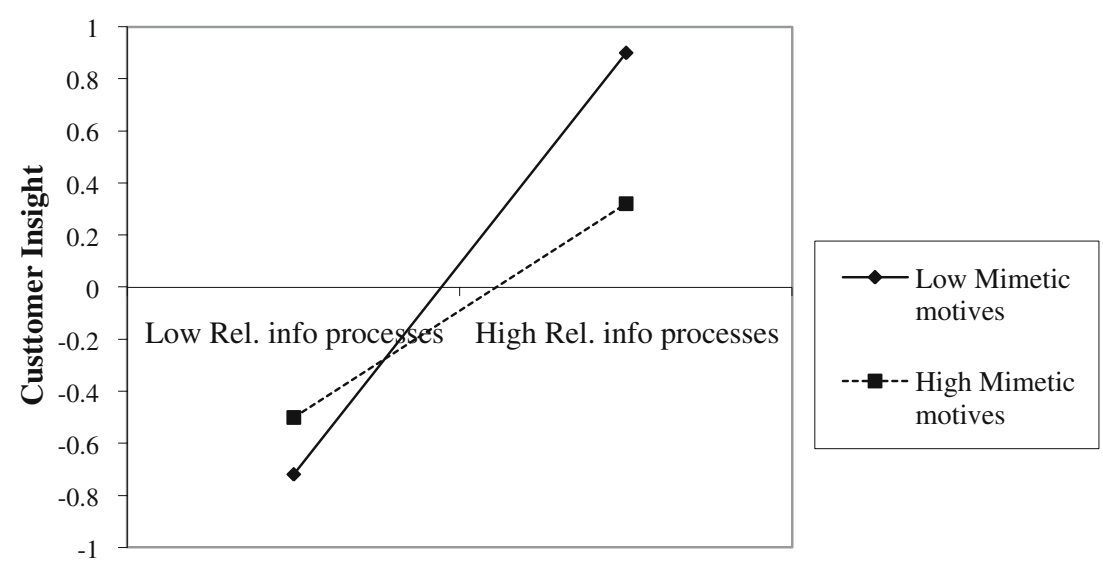


Table 3 Results of hypothesis tests

\begin{tabular}{|c|c|c|c|c|c|}
\hline Hypothesis \# & Interaction & Dependent variable & Expected result & Empirical result & Conclusion \\
\hline 1a & Mimetic motives x CRM system & Relational information processes & Negative & N.S. & Not supported \\
\hline $1 b$ & $\begin{array}{l}\text { Customer intimacy strategy } \mathrm{x} \\
\text { Mimetic motives x CRM system }\end{array}$ & Relational information processes & Negative & Negative & Supported \\
\hline $2 \mathrm{a}$ & $\begin{array}{l}\text { Mimetic motives } \mathrm{x} \text { Relational } \\
\text { information processes }\end{array}$ & Customer insights & Negative & Negative & Supported \\
\hline $2 b$ & $\begin{array}{l}\text { Customer intimacy strategy x } \\
\text { Mimetic motives x Relational } \\
\text { information processes }\end{array}$ & Customer insights & Negative & N.S. & Not Supported \\
\hline
\end{tabular}

turns out not to be significant $(b=.13, p>.10)$. It suggests that the two-way interaction (Hypothesis $1 \mathrm{~b}$ ) represents a fairly robust finding in the sense that irrespective of the degree to which the firm follows a customer intimacy strategy, mimetic motives negatively moderate the relationship between relational information processes and customer insights.

To summarize, Table 3 provides an overview of the hypotheses and shows whether the empirical data support them.

\section{Control variables}

Finally, the results regarding our control variables show that industry has a positive effect on relational information processes and a negative effect on customer relationship performance. ${ }^{6}$ In other words, service firms, compared to their product-based counterparts, seem to process more relational information, but to enjoy lower performance spillovers where loyal customer relationships are concerned. The former may be explained by relationship management being more important for service firms (Palmatier et al. 2006), encouraging service firms to pay more attention to information processing. The negative effect on customer relationship performance may be due to switching being easier in many service sectors. Firm size only has a (negative) effect on relational information processes. Maybe large firms find it more difficult to organize for structured information processing. Customercentric management system does not have an effect on any of the dependent variables. Top management involvement has a negative effect on customer insights but a marginally significant positive effect on customer relationship performance. While top management seems to be able to focus its organization on generating customer loyalty outcomes, it

\footnotetext{
${ }^{6}$ To be sure that other industry effects beyond the product/service distinction did not confound our results, we also explored models with separate dummies per industry categories (modeling industry dummies on one dependent variable at a time). No evidence for such influences was detected.
}

seems to be less able to manage, and affect, the generation of customer insights.

\section{Discussion}

Our study focuses on the effects of mimetic motives on CRM effectiveness and the results show that these effects are more complex than anticipated given the different results for the left and right-hand sides of our model. On the left-hand side of the model, we found no support for a negative moderating effect of mimetic motives (as expected in Hypothesis 1a). A closer inspection (see Fig. 2) reveals that under the condition of high customer intimacy strategy mimetic motives negatively affect the relationship between CRM system and relational information processes, as expected. However, under conditions of low customer intimacy this moderating effect turns out to be positive. A possible explanation for this result is that the firms responding to mimetic pressures are less selective in the collection, integration and analysis of customer information than their counterparts. That is, these firms may employ a rather mechanistic behavior of collecting, storing and analyzing data; having invested in a serious CRM system, management and marketing staff make sure it is also filled and used. This might imply that an unquestioning approach to the possibilities of the CRM technology in use results in a poor distinction between useful and irrelevant information, resulting in a CRM system pushing the firm to process more rather than less information.

Our results show that there is a strong difference in the extent of CRM-related activity for firms operating under different conditions. Firms characterized by high mimetic motives, low levels of customer intimacy strategy, as well as limited investments in their CRM system are associated with few relational information processes activities (see Fig. 2). This seems to reflect instances of ceremonial adoption. Such ceremonial adoption of CRM results in collecting, storing and analyzing less customer data than in situations where mimetic motives are low. In contrast, we find that firms operating under a customer intimacy strategy 
face no detrimental effect of strong mimetic motives. On the contrary, these firms register, store and analyze more customer data than their counterparts that score low on customer intimacy strategy, suggesting that a strategic fit between the focal practice and firms buffers the latter from the potentially negative consequences of adopting under mimetic pressures. This is consistent with our argumentation that strategic alignment helps ensure correct implementation by making adequate adjustments and customization decisions. It points to more careful implementation even when socially pressured to adopt. On the right-hand side of the model the effects of mimetic motives are less complex. Here we see that firms that adopted CRM because of mimetic motives are less likely to generate such insights from their information processing activities than their less mimetic motives driven competitors. Remarkably, this effect is not moderated further by customer strategy of the firm. So, the anticipated compensating or buffering influence of customer intimacy strategy on mimetic motives (as suggested in Hypothesis 2b) is not encountered. Maybe extracting customer insights from information processing activities is such a subtle process that it always requires the right motivation and cannot be compensated by having a customer intimacy strategy. The lack of support for Hypothesis $2 b$ thus confirms that mimetic motives have a negative influence on the effectiveness of this marketing practice. These effects are arguably more important than the effects on the left-hand side of the model, since relational information processing is merely a means to the end of CRM-generating customer insights that help building and maintaining customer relationships (Mithas et al. 2005).

Although customer intimacy strategy does not buffer the negative influence of mimetic motives on the relational information processes-customer insights relationship, we do find a positive interaction effect between customer intimacy strategy and mimetic motives on customer insights. Hence, firms with a customer intimacy strategy that adopt CRM for mimetic reasons develop more customer insights than firms that feel less pressured by their social environment. Note that these insights are not related to the firm's CRM information processing activities and their contribution to enhanced insights. In other words, firms that adopt for mimetic reasons appear to realize additional customer insights simply because they draw attention to and promote the CRM philosophy amongst their employees, independent of the extent to which relational information processes are performed.

Taken together, our results suggest that mimetic motives and customer intimacy strategy jointly influence CRM effectiveness, but in different ways. Our use of mimetic motives represents an institutional perspective which argues that adoption induced by social pressures is likely to result in superficial implementation and thus lower effectiveness.
On the other hand, our results suggest that customer intimacy strategy entails a better understanding of CRM, a more thorough implementation, and hence a higher effectiveness. While conceptually not a motive for CRM adoption, customer intimacy strategy acts as a proxy for a more rational perspective on CRM adoption in the sense that for firms following a customer intimacy strategy, the decision to adopt CRM makes more sense. Both CRM and a strategic focus on customer intimacy draw from the same philosophical underpinnings and allow for a coherent strategic fit. Mimetic motives and customer intimacy strategy thus have differential effects on the quality of implementation of CRM, where the latter may counterbalance the former.

\section{Institutional theory and CRM effectiveness}

While institutional theory is usually used as a theoretical framework for explaining the adoption of practices (Heugens and Lander 2009; Westphal et al. 1997), our study suggests that it is also helpful for understanding the effectiveness of practices. In the case of CRM, the motivations for adoption carry over in the effective use of this marketing practice. While previous studies have tried to explain the lack of CRM success by focusing on technical, people or organizational factors (e.g., Ahearne et al. 2008; Becker et al. 2009; Plakoyiannaki et al. 2008; Raman et al. 2006; Reinartz et al. 2004), our study suggests that institutional processes are also an important factor. Competitors, the media, and other trendsetters may pressure a firm to adopt CRM, which may have negative consequences in terms of its effectiveness if firms are motivated merely to conform to such pressures. Such social context factors have been all but ignored in the study of the effectiveness of marketing practices, but our study suggests that they can at least partly explain the mixed results for CRM effectiveness reported in the literature. Particularly with the current trend to increase the focus on accountability of marketers and marketing's contribution to the bottom line of the firm (Verhoef and Leeflang 2009), sensitivity for motives for adoption and their influence on marketing practice effectiveness would seem appropriate. Our study thus adds to and can give an extra impulse to marketing accountability research.

\section{Managerial implications}

Our study is also relevant to managers. It provides them a deeper insight into why and when their CRM investments are likely to be more successful. It warns them not to adopt CRM only because competitors are using it or because it is suggested by trade journals or management gurus. Rather they should adopt it based on an in-depth understanding of 
the value and goals of CRM. Such an understanding makes it more likely that they will use CRM in such a way that they will gain insights into the demands of the customers. Since the reasons for adopting CRM systems (at the beginning of the CRM project) are an important factor for the effectiveness of the CRM investments, these insights provide managers with an early opportunity to decide whether or not to pursue CRM. It can help prevent the need for taking corrective actions at a later date, which tends to be very costly because these often involve the need for a different CRM architecture and software supplier.

Based on our results we would like to stress that, while the motivation for imitative behavior matters, the act of imitation is not necessarily hurtful to firms. Earlier work has already suggested that the inferential learning from competitors which sometimes leads to imitation can be a highly efficient way to judge practice efficacy and appropriateness for the firm (Greve 1998). In addition, our study shows that giving in to institutional pressures reduces a firm's ability to gain performance benefits from adoption, but that this can be mitigated when firms choose to adopt a practice which fits with their strategy. Together, these insights would suggest that imitation in and of itself does not always have negative performance consequences. Furthermore, even having shown that mimetic motives may have negative consequences for practice effectiveness, this is not to say that managers should never entertain such mimetic motives. In cases where firms stand to gain significant legitimacy benefits through adoption, managers may choose to adopt practices merely ceremoniously. In such cases practice effectiveness is relatively unimportant and may not even be expected. However, a careful consideration of the trade-off between required (minimal) investments and legitimacy benefits is key for such ceremonial adopters (Brunsson 1991; Deephouse and Carter 2005). Future research may investigate the extent to which antecedents like practice adoption impact firm legitimacy.

\section{Limitations and further research}

Our study has several limitations, which also offer areas for further research. First, while our research shows how mimetic motives for adoption influence CRM effectiveness, it should be noted that DiMaggio and Powell (1983) identified three types of institutional isomorphism; in addition to mimetic pressures, they discussed coercive and normative pressures. It has been noted that mimetic isomorphism has received disproportionate attention in studies that empirically address these institutional pressures (Mizruchi and Fein 1999), and our study also focused on only this one type of pressure. Nonetheless, we do suggest that researching all three types of pressures will be useful.
Second, given our intention to show the applicability of the institutional perspective to practice effectiveness, we have chosen to disregard the traditional, rational view on practice adoption and diffusion. However, while our measure for mimetic motives is indeed intended to capture social pressures that encourage firms to adopt CRM (e.g., by formulating the items in a passive way), we cannot completely rule out the possibility that it also taps into more rational considerations for imitating CRM. As the data show that, overall, mimetic motives have a negative effect, we suggest that if our scale of mimetic motives indeed reflects both perspectives, we do believe the institutional perspective dominates the rational perspective. If imitators of CRM did so because of rational considerations, this would entail (inferential) learning from the performance of competitors and a careful analysis of costs and benefits of adoption given the context of the own organization. Under such circumstances the moderating effect of mimetic motives on the CRM model is unlikely to be negative. Nonetheless, we did find support for a negative effect.

As a result of our decision to focus on an institutional perspective on practice effectiveness rather than a rational perspective, it remains a question which perspective has more explanatory power in understanding diffusion and effectiveness of marketing effectiveness. By including a measure of strategic fit, we have attempted to take into account the extent to which it would be arguably more rational to adopt CRM. However, a more direct appraisal of the extent to which decision making on practice adoption occurs in a rational manner, versus being socially driven, is likely to result in a better test of these perspectives. More specifically, we encourage future researchers to account for both the institutional and rational perspective on imitation and develop a new measure for mimetic motives with separate items for both perspectives.

In a similar vein, future research should take account of the specific institutional mechanisms through which reacting to social pressures results in negative performance consequences. We have proposed that the mechanisms behind the negative effects of mimetic motives are a lack of deep understanding of the CRM practice, a failure to adapt to firm-specific contingencies because the effectiveness of CRM is simply taken for granted, and a desire to gain legitimacy benefits with less interest in the practice itself, the latter leading to instances of strictly ceremonial adoption. We believe that there are subtle yet profound attitudinal and cognitive differences between these mechanisms (Kostova and Roth 2002), and that these differences may vary in the size of their impact on practice effectiveness (with ceremonial adoption likely to be the most detrimental). Further research is needed to identify and gauge which of these mechanisms is the most important mediator explaining the negative impact of mimetic motives. 
It should be noted that while we studied a dynamic phenomenon, our data is cross-sectional in nature. As a result inferences regarding causality should be interpreted with caution. Future research with longitudinal data could test whether the assumed causality holds.

Our choice of sample frame has both constrained the sample size and scope (i.e., companies from one country). Replications in other countries would extend the generalizability of our results. While we controlled for product versus service industries, future research may focus on specific industries and CRM outcomes, exploring differences between various industries. For example, Becker et al. (2009) argue that CRM yields far better results in the financial services than in other industries. Such efforts should preferably use larger samples.

As the amount of time between when a practice first gains popularity and its adoption by the focal unit may be an antecedent of mimetic motives, with later adopters being generally more driven by mimetic considerations, further inquiry into the effects of moment of adoption would also be useful. This might be combined with differentiating between economic and ceremonial performance of a marketing practice. Last but not least, we suggest that our institutional theory-based insights are likely to be applicable in other areas of marketing research and practice. For instance, mimetic motives may have played a role in firms' decisions to use loyalty cards (Mägi 2003) or marketing dashboards (Pauwels et al. 2009) amongst others.

\section{Conclusion}

The results of the study suggest that institutional theory contributes to our understanding of the effectiveness of marketing practices. More specifically, our study has shown that mimetic motives can reduce a firm's ability to obtain valuable customer insights from their CRM efforts. Managers, therefore, need to pay attention to the motivation for adoption. High levels of mimetic motives may jeopardize reaping benefits from CRM investments because even firms with careful alignment of their CRM activities with customer strategy tend to gain less in their understanding of customer needs and behaviors.

As marketing practices have been scrutinized only to a limited extent and studies on fads and fashions in marketing practices have not developed extensively, we call for further research drawing on institutional theory. This should result in a more socialized view of the adoption and effectiveness of marketing practices.

Acknowledgements We thank the four anonymous reviewers and G. Tomas M. Hult for their guidance and helpful comments. Furthermore, we would like to thank David Dekker, Maurice Howldar, and Michel van der Borgh for their assistance in data gathering and analysis.

Open Access This article is distributed under the terms of the Creative Commons Attribution Noncommercial License which permits any noncommercial use, distribution, and reproduction in any medium, provided the original author(s) and source are credited.

\section{Appendix A}

Measurement items of study constructs

\begin{tabular}{ll}
\hline Construct & Measurement \\
\hline CRM system & 1. We have a customer information system that is fully automated. \\
2. In our organization several software applications regarding customer information are linked to a \\
network. \\
3. In our organization software applications for analyzing customer information are present. \\
4. We have an automated system that supports individual and group decisions regarding customers. \\
5. In our organization our automated customer information system is integrated with other \\
communication systems (switchboard operators, complaints services, etc). \\
1. Our organization has implemented CRM in response to what competitors were and are doing. \\
2. Our choice for CRM is clearly influenced by large attention for CRM from the management press \\
and management consultants. \\
3. Our choice to implement CRM was strongly influenced by what others in the industry are doing. \\
Compared to our competitors, in the strategy of our firm the emphasis is on... \\
1. Building long lasting relationships with customers. \\
2. Offering customized products to our customers. \\
3. Offering our customers the best products for their needs all the time.
\end{tabular}


(continued)

$\begin{array}{lll}\text { Construct } & \text { Measurement } & \text { PLS factor } \\ & \text { loading }\end{array}$

Relational information Registration

processes

1. We collect customer information on an ongoing basis.

2. We capture customer information from internal sources within the organization.

3. We collect customer information using external sources (such as market research agencies, syndicated data sources, and consultants).

4. The information collected from customers is updated in a timely fashion.

5. We use customer interactions to collect information.

Integration

6. We systematically integrate customer information from the various functions that interact with customers (such as marketing, sales, and customer service).

7. We systematically integrate internal customer information with external customer information.

8. We integrate, as much as we can, customer information from different communication channels (such as telephone, mail, e-mail, internet, fax, and personal contact) and different functions.

9. We systematically merge information collected from various sources for each customer.

Analysis

10. We use customer information to develop customer profiles.

11. We systematically use customer information to segment markets.

12. We analyze customer information to assess customer retention behavior.

13. We use customer information to identify appropriate channels to reach customers.

14. We use customer information to customize our offers.

Customer insights $\quad$ We know...

1. Very well who our customers are.

2. Which of ours means of communication are most valued by our customers.

3. What the underlying needs of our customers are.

4. How needs of our customers change through time.

5. Which customers want an intensive relationship with us and why. $\quad .83$

6. What it is that customers value specifically in our offers.

7. Why customers buy from us and not from competitors $\quad .75$

8. Why some customers do not buy from us anymore.

Customer relationship performance

Relative to our most important competitors...

1. Based on good experiences, our customers regularly express themselves positively about us. $\quad .80$

2. Our customers are repeat buyers of products. $\quad .87$

3. We have relatively many loyal customers.

1. CRM has been implemented in our organization in a top-down manner. $\quad .91$

2. Our choice for CRM has been strongly influenced by top management. $\quad .78$

3. Top management played a large role in shaping and fleshing out CRM in our organization. $\quad .93$

$\begin{array}{ll}\text { 1. We focus on customer needs when designing business processes. } & .87\end{array}$

2. Business processes are designed to enhance firm-customer interactions.

3. We organize ourselves around customer groups rather than functional groups. $\quad .75$

\section{References}

Abrahamson, E. (1991). Managerial fads and fashions: the diffusion and rejection of innovations. Academy of Management Review, $16(3), 586-612$.

Abrahamson, E. (1996). Management fashion. Academy of Management Review, 21(1), 254-285.

Ahearne, M., Jones, E., Rapp, A., \& Mathieu, J. (2008). High touch through high tech: the impact of salesperson technology usage on sales performance via mediating mechanisms. Management Science, 54(4), 671-85.

Aiken, L. S., \& West, S. G. (1991). Multiple regression: Testing and interpreting interactions. Newbury Park: Sage.

Alavi, M., \& Leidner, D. (2001). Knowledge management and knowledge management systems: conceptual foundations and research issues. MIS Quarterly, 25(1), 107-136.

Ansari, S. M., Fiss, P. C., \& Zajac, E. J. (2010). How practices vary as they diffuse: a framework for analysis. Academy of Management Review, 35(1), 67-92. 
Armstrong, J. S., \& Overton, T. S. (1977). Estimating nonresponse bias in mail surveys. Journal of Marketing Research, 14(3), 396-402.

Barclay, D. W., Higgins, C., \& Thompson, R. (1995). The partial least squares (PLS) approach to causal modeling: personal computer adaptation and use as an illustration. Technology Studies, 2(2), 285-309.

Becker, J. U., Greve, G., \& Albers, S. (2009). The impact of technological and organizational implementation of CRM on customer acquisition, maintenance, and retention. International Journal of Research in Marketing, 26(3), 207-215.

Bohling, T., Bowman, D., LaValle, S., Mittal, V., Narayandas, D., Ramani, G., et al. (2006). CRM implementation: effectiveness issues and insights. Journal of Service Research, 9(2), 184-194.

Boiral, O. (2007). Corporate greening through ISO 14001: a rational myth? Organization Science, 18(1), 127-146.

Boulding, W., Staelin, R., Ehret, M., \& Johnston, W. J. (2005). A customer relationship management roadmap: what is known, potential pitfalls, and where to go. Journal of Marketing, 69(4), $155-166$.

Brunsson, N. (1991). The organization of hypocrisy: Talk, decisions and actions in organizations. Copenhagen: Copenhagen Business School.

Burns, L. R., \& Wholey, D. R. (1993). Adoption and abandonment of matrix management programs: Effects of organizational characteristics and interorganizational networks. Academy of Management Journal, 36(1), 106-138.

Campbell, A. J. (2003). Creating customer knowledge competence: managing customer relationship management programs strategically. Industrial Marketing Management, 32(5), 375-383.

Chin, W. W. (1998). The partial least squares approach to structural equations modeling. In G. A. Marcoulides (Ed.), Modern methods for business research (pp. 295-336). London: Erlbaum.

Conant, J. S., Mokwa, M. P., \& Varadarajan, P. R. (1990). Strategic types, distinctive marketing competences and organizational performance: a multiple measures-based study. Strategic Management Journal, 11(5), 365-383.

Deephouse, D. L., \& Carter, S. M. (2005). An examination of differences between organizational legitimacy and organizational reputation. Journal of Management Studies, 42(2), 329-360.

Dickie, J. (2004). Does $\mathrm{CRM}=$ sales effectiveness or sales ineffectiveness. Retrieved October 16, 2008 from http://siebel. ittoolbox.com/documents/industry-articles/does-crm-saleseffectiveness-or-sales-ineffectiveness- 1508 .

DiMaggio, P. J., \& Powell, W. W. (1983). The iron cage revisited: institutional isomorphism and collective rationality in organizational fields. American Sociological Review, 48, 147-160.

Fornell, C., \& Larcker, D. F. (1981). Structural equation models with unobservable variables and measurement error: algebra and statistics. Journal of Marketing Research, 18(3), 382-388.

Greve, H. R. (1998). Managerial cognition and the mimetic adoption of market positions: what you see is what you do. Strategic Management Journal, 19, 967-988.

Grewal, R., \& Dharwadkar, R. (2002). The role of the institutional environment in marketing channels. Journal of Marketing, 82(3), 82-97.

Guillén, M. (1994). Models of management. Ithaca: Cambridge University Press.

Haunschild, P. R., \& Miner, A. S. (1997). Modes of interorganizational imitation: the effects of outcome salience and uncertainty. Administrative Science Quarterly, 42(4), 472-500.

Hendricks, K. B., Singhal, V. R., \& Stratman, J. K. (2006). The impact of enterprise systems on corporate performance: a study of ERP, SCM, and CRM system implementations. Journal of Operations Management, 25(1), 65-82.
Heugens, P. P. M. A. R., \& Lander, M. W. (2009). Structure! Agency! (and other quarrels): meta-analyzing institutional theories of organization. Academy of Management Journal, 52(1), 61-85.

Homburg, C., Workman, J. P., Jr., \& Krohmer, H. (1999). Marketing's influence within the firm. Journal of Marketing, 63(4), 1-17.

Homburg, C., Droll, M., \& Totzek, D. (2008). Customer prioritization: does it pay off, and how should it be implemented? Journal of Marketing, 72(5), 110-30.

Huang, X., Gattiker, T. F., \& Schroeder, R. G. (2010). Do competitive priorities drive adoption of electronic commerce applications? Testing the contingency and institutional views. Journal of Supply Chain Management, 46(3), 57-69.

Iyer, G. R. (1997). Comparative marketing: an interdisciplinary framework for institutional analysis. Journal of International Business Studies, 28(3), 531-561.

Jayachandran, S., Sharma, S., Kaufman, P., \& Raman, P. (2005). The role of relational information processes and technology use in customer relationship management. Journal of Marketing, 69(4), 177-192.

Kennedy, M. T., \& Fiss, P. C. (2009). Institutionalization, framing, and diffusion: the logic of TQM adoption and implementation decisions among U.S. hospitals. Academy of Management Journal, 52(5), 897-918.

Kohli, A., \& Jaworski, B. J. (1990). Market orientation: the construct, research propositions, and managerial implications. Journal of Marketing, 54(2), 1-18.

Kostova, T., \& Roth, K. (2002). Adoption of an organizational practice by subsidiaries of multinational corporations: institutional and relational effects. Academy of Management Journal, 45(1), $215-233$

Krasnikov, A., Jayachandran, S., \& Kumar, V. (2009). The impact of customer relationship management on cost and profit efficiencies: evidence from the U.S. commercial banking industry. Journal of Marketing, 73(11), 61-76.

Lindell, M. K., \& Brandt, C. J. (2000). Climate quality and climate consensus as mediators of the relationship between organizational antecedents and outcomes. Journal of Applied Psychology, 85(3), 331-348.

Lounsbury, M. (2001). Institutional sources of practice variation: staffing college and university recycling programs. Administrative Science Quarterly, 46(1), 29-56.

Mägi, A. W. (2003). Share of wallet in retailing: the effects of customer satisfaction, loyalty cards and shopper characteristics. Journal of Retailing, 79(2), 97-106.

Meyer, J. W., \& Rowan, B. (1977). Institutionalized organizations: formal structure as myth and ceremony. American Journal of Sociology, 83(2), 340-363.

Mithas, S., Krishnan, M. S., \& Fornell, C. (2005). Why do customer relationship management applications affect customer satisfaction? Journal of Marketing, 69(4), 201-209.

Mizruchi, M. S., \& Fein, L. C. (1999). The social construction of organizational knowledge: a study of the uses of coercive, mimetic, and normative isomorphism. Administrative Science Quarterly, 44(4), 653-683.

Morgan, R. M., \& Hunt, S. D. (1994). The commitment-trust theory of relationship marketing. Journal of Marketing, 58(3), 20-38.

Narver, J. C., \& Slater, S. F. (1990). The effect of a market orientation on business profitability. Journal of Marketing, 54(4), 20-35.

Nunnally, J. C. (1978). Psychometric theory (2nd ed.). New York: McGraw-Hill.

Oliver, C. (1991). Strategic responses to institutional processes. Academy of Management Review, 16(2), 145-179.

Palmatier, R. W., Dant, R. P., Grewal, D., \& Evans, K. R. (2006). Factors influencing the effectiveness of relationship marketing: a meta-analysis. Journal of Marketing, 70(4), 136-153. 
Pauwels, K., Ambler, T., Clark, B. H., LaPointe, P., Reibstein, D., Skiera, B., et al. (2009). Dashboards as a service: why, how, and what research is needed? Journal of Service Research, 12(2), $175-189$.

Payne, A. (2006). Handbook of CRM: Achieving excellence in customer management. Burlington: Butterworth-Heinemann.

Payne, A., \& Frow, P. (2005). A strategic framework for customer relationship management. Journal of Marketing, 69(4), 167-176.

Plakoyiannaki, E., Tzokas, N., Dimitratos, P., \& Saren, M. (2008). How critical is employee orientation for customer relationship management? Insights from a case study. Journal of Management Studies, 45(2), 268-293.

Podsakoff, P. M., \& Organ, D. W. (1986). Self-reports in organizational research: problems and prospects. Journal of Management, 12, 69-82.

Raman, P., Wittmann, C. M., \& Rauseo, N. A. (2006). Leveraging CRM for sales: the role of organizational capabilities in successful CRM implementation. Journal of Personal Selling \& Sales Management, 26(1), 39-53.

Rao, R. S., Chandy, R. K., \& Jaideep Prabhu, J. (2008). The fruits of legitimacy: why some new ventures gain more from innovation than others. Journal of Marketing, 72(4), 58-75.

Reinartz, W., Krafft, M., \& Hoyer, W. D. (2004). The customer relationship management process: its measurement and impact on performance. Journal of Marketing Research, 41(3), 293-305.

Reinartz, W., Haenlein, M., \& Henseler, J. (2009). An empirical comparison of the efficacy of covariance-based and variancebased SEM. International Journal of Research in Marketing, 26 (4), 332-344.

Ringle, C. M., Wende, S., \& Will, A. (2005). SmartPLS 2.0 (beta) http:// www.smartpls.de, University of Hamburg, Hamburg, Germany.

Robey, D., Boudreau, M.-C., \& Rose, G. M. (2000). Information technology and organizational learning: a review and assessment of research. Accounting Management and Information Technologies, 10(2), 125-155.

Rogers, E. M. (1995). Diffusion of Innovations (5th ed.). New York: Free.

Sinkula, J. M. (1994). Market information processing and organizational learning. Journal of Marketing, 58(1), 35-45.

Slater, S. F., \& Narver, J. C. (1995). Market orientation and the learning organization. Journal of Marketing, 59(3), 63-74.

Srinivasan, R., \& Moorman, C. (2005). Strategic firm commitments and rewards for customer relationship management in online retailing. Journal of Marketing, 69, 193-200.

Srivastava, R. K., Shervani, T. A., \& Fahey, L. (1999). Business processes and shareholder value: an organizationally embedded view of marketing activities and the discipline of marketing. Journal of Marketing, 63(SI), 168-180.

Staw, B. M., \& Epstein, L. D. (2000). What bandwagons bring: effects of popular management techniques on corporate performance, reputation and CEO pay. Administrative Science Quarterly, 45, 523-556.

Stratman, J. K. (2007). Realizing benefits from enterprise resource planning: does strategic focus matter? Production and Operations Management, 16(2), 203-216.

Terlaak, A., \& Gong, Y. (2008). Vicarious learning and inferential accuracy in adoption processes. Academy of Management Review, 33(4), 846-868.

Tolbert, P. S., \& Zucker, L. G. (1996). The institutionalization of institutional theory. In S. Clegg, C. Hardy, \& W. Nord (Eds.), Handbook of organization studies (pp. 175-190). London: Sage.

Treacy, M., \& Wiersema, F. (1993). Customer intimacy and other value disciplines. Harvard Business Review, 71(1), 84-93.

Verhoef, P. C., \& Leeflang, P. S. H. (2009). Understanding the marketing department's influence within the firm. Journal of Marketing, 73(2), 14-37.

Voss, G. B., \& Voss, Z. G. (2008). Competitive density and the customer acquisition-retention trade-off. Journal of Marketing, 72(6), 3-18.

Westphal, J. D., \& Zajac, E. J. (2001). Decoupling policy from practice: the case of stock repurchase programs. Administrative Science Quarterly, 46(2), 202-228.

Westphal, J. D., Gulati, R., \& Shortell, S. M. (1997). Customization or conformity? An institutional and network perspective on the content and consequences of TQM adoption. Administrative Science Quarterly, 42, 366-394.

Whitmore, M., \& Copulsky, J. (2003). CRM R.I.P.?: It was overhyped, over-promised and over-sold. But is CRM truly dead? Marketing Magazine, 108(13), 13-14.

Woodruff, R. B. (1997). Customer value: the next source for competitive advantage. Journal of the Academy of Marketing Science, 25(2), 139-153.

Wouters, M., \& Wilderom, C. (2008). Developing performancemeasurement systems as enabling formalization: a longitudinal field study of a logistics department. Accounting, Organizations and Society, 33(4-5), 488-516.

Wu, F., Mahajan, V., \& Balasubramanian, S. (2003). An analysis of e-business adoption and its impact on business performance. Journal of the Academy of Marketing Science, 31(4), 425-447.

Yim, F. H., Anderson, R. E., \& Swaminathan, S. (2004). Customer relationship management: its dimensions and effect on customer outcome. Journal of Personal Selling \& Sales Management, 24 (4), 263-278. 